Sign Systems Studies 32.1/2, 2004

\title{
History and significance of Jakob von Uexküll and of his institute in Hamburg
}

\author{
Torsten Rüting \\ Jakob von Uexküll-Archiv für Umweltforschung und Biosemiotik, \\ Fachbereich 11, Universität Hamburg, \\ Bundesstr. 55, 20146 Hamburg, Germany \\ e-mail: rueting@math.uni-hamburg.de
}

\begin{abstract}
This paper aims to give an insight into developments that contributed to the significance of the work of Jakob von Uexküll and stresses the importance of his occupation in Hamburg. A biographical survey pays tribute to the implication of the historical pretext and context. A scientific survey describes findings and ideas of Uexküll that proved important for the development of biology and the cognitive sciences. In addition, this paper sets out to reject the common notion that Uexküll's concepts were ideas of a purely theoretical and philosophical character. It confirms that in fact the central aims of his work were to sustain the empirical method in biology and to give biology a sound epistemological basis. Some examples show how historical and theoretical developments converged at Uexküll's Institut für Umweltforschung in Hamburg and ignited a productive research activity.
\end{abstract}

\section{Introduction}

Realisation of ideas in Hamburg

At the age of 61 Jakob von Uexküll (1864-1944) came to work and teach at the University of Hamburg. In April 1925 he was employed as "Wissenschaftlicher Hilfarbeiter" (scientific assistant worker), "a position almost comically beneath a man of his years and experience" (Harrington 1996: 35). However, at the end of the year he was appointed Honorarprofessor. For Uexküll these were the first paid positions in his career, and it seems that his long lifespan as an independent biologist was both an expression and guarantee for the creativity of his mind. Uexküll's career in Hamburg can be taken as a 
demonstration of the unbroken vigour of his mind and his creativeness. He founded the Institut für Umweltforschung and Hamburg became the place where the wealth of his ideas and his original ideas about biological research, summarised in his Theoretische Biologie (1920a), could be realised within an academic institution for the first time. Uexküll turned out to be a talented director and manager, who mastered the obstacles of bureaucracy and deficiency in inter-war Germany. His winning personality and intellectual spirit attracted and motivated scientists of different educational backgrounds and origins to take part in research at the institute. Besides teaching, supervising students and co-workers, and managing the institute, Uexküll found time to unfold his creativity and published many books that made his insights popular and won him fame.

In Hamburg Uexküll (Fig. 1) put into action his continuous striving for a sound foundation of biology in epistemology and experimentation. In his publications from around 1900 Uexküll had already emphasised that biology had gone astray into speculation and had to win back the experimental method from physiology. This was after more than ten years of thorough studies on the physiology of invertebrate animals in the laboratories of Wilhelm Kühne (1837-1900) in Heidelberg and Anton Dohrn (1840-1909) in Naples, where Uexküll had introduced innovative experimental technology like the cinematograph. Uexküll's promotion of the experimental method in biology went hand in hand with a revision of its epistemological foundations. In his second book, Umwelt und Innenwelt der Tiere (1909), he simultaneously criticised the positivistic idea of scientific progress and of progress in evolution. He dedicated a whole chapter to the problem of "the observer" - the main problem of epistemology in science. According to Uexküll, studying the biology of animals provided basic insights into the process of investigation itself.

However, not until the mid-twenties did the Institut für Umweltforschung become the place where Uexküll's Theoretische Biologie was used for heuristic orientation by a larger group of scientists for the first time. Uexküll's original concepts were the guidelines for research in the Institut für Umweltforschung and his theoretical thoughts structured the explanation of its results. The number of students and researchers at the institute grew rapidly and by 1934 more than 70 papers had been published. Nevertheless, Uexküll's ideas were not acknowledged unanimously by his colleagues in the 
faculty and the Institut for Umweltforschung barely survived the death of its founder. It was finally closed in 1960 - as early as the 1970s this was regretted as being untimely, since new institutions for the investigation of the so called Umweltproblem, "environmental problem", were to be founded anew.

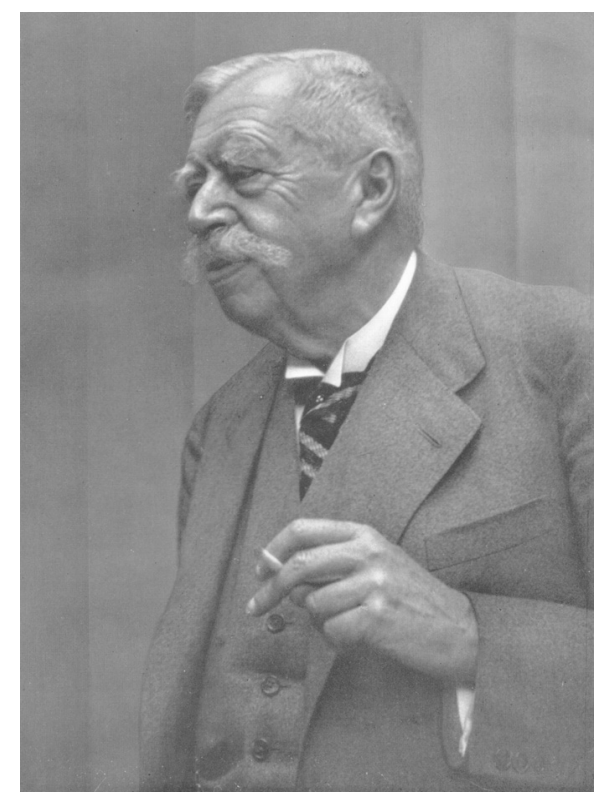

Figure 1. Jakob von Uexküll celebrating his 70th birthday in his institute in Hamburg.

Significance of Uexküll to 20th and 21 st century thought

In the eyes of contemporary biologists, Uexküll often appeared arrogant, and his sharp tongue provoked tensions and incomprehension; his unfamiliar ideas were rejected and he himself was labelled a vitalist, anti-evolutionist or mystic (e.g., by Goldschmidt 1956). However scholars in different fields of science and the arts, like psychology, anthropology, philosophy, linguistics, architecture and literature, have recognised the resourceful significance of his challenge (for a 
detailed list see Kull 2001). Most notably Uexküll's approach influenced the development of the Organismic Biology and System Theory of Ludwig von Bertalanffy (1901-1972) and the ethology of Konrad Lorenz (1903-1989) and Nico Tinbergen (1907-1988) (Schmidt 1980).

The topicality and inter-disciplinarity of Uexküll's ideas has been demonstrated at several conferences over the last decade. A special issue of the journal Semiotica (vol. 134, 2001) brought together the contributions of scholars from linguistics to cybernetics and molecular biology, who explored the legacy of Uexküll in their fields of research. In addition to the rise of the "semiotic turn", the renewed interest in Uexküll's works has been explained as coinciding with a "trend from temporal (evolutionary, genetic, "vertical") biology towards spatial (organismic, genomic, "horizontal") biology" (Kull 2001: 4). Uexküll's agenda is seen as "a main contribution to the 'developmental' or 'epigenetic' trend in the biology of the recent centuries; a lineage involving scholars like Karl Ernst von Baer, d'Arcy Thompson, Hans Spemann, Hans Driesch, Conrad Hal Waddington, Brian Goodwin, René Thom, Robert Rosen and Stuart Kauffman" (Stjernfelt 2001: 79).

The significance of Uexküll's writings is also demonstrated in the recent works of philosophers. Peter Sloterdijk (2004) acknowledges Uexküll's conception of Umwelt and his critique of metaphysics as being relevant for the description of the ethical crisis immanent in the processes of modern society and globalisation. Giorgio Agamben (2002) discusses the relevance of Uexküll to the development of modern philosophy and ideology in the sense of bioethics. The historian of science Anne Harrington (1996) recently described Uexküll in the context of holistic thought in interwar Germany.

\section{Biographical survey}

Youth in the Baltic aristocracy

Jakob von Uexküll was born on the manor of Keblaste (Mihkli) in Estonia on the 8th of September 1864. He was the fifth child in an aristocratic German-Baltic family. His mother Sophie von Hahn was from Kurland. His father Alexander von Uexküll had broad interests. During his young years as a geologist he had explored the natural 
history of the Urals. Between 1875 and 1877 the family went to Germany were Jakob attended the Gymnasium in Coburg. In 1877 his family returned to Estonia were his father had been appointed mayor of Reval (now Tallinn). Jakob was sent to the Domschule, whose rector was at that time the father of the future Gestalt-psychologist Wolfgang Köhler. In 1884, on completing his Abitur, Uexküll studied zoology in Dorpat (now Tartu). He graduated with the academic degree Kandidat der Zoologie (candidate of zoology) and during his life never took another academic examination. At first attracted by the materialistic and deterministic world view, Uexküll became critical of the simplistic explanations of the Darwinists. One of his teachers in Dorpat was Julius von Kennel (1852-1939), whose speculations about the ancestral lines of animals left Uexküll dissatisfied with the science of biology (G. v. Uexküll 1964: 35ff).

\section{From experimental physiology to a new conception of biology}

In 1890 Uexküll went to study physiology in Heidelberg at the physiological laboratory of Wilhelm Kühne (1837-1900), who had been born in Hamburg. He introduced himself to Kühne as "deserter from biology" and worked and studied in this famous laboratory for more than a decade. Uexküll thought that physiologists had refrained from speculation and that their experimental methods could serve to renew biology. He specialised in the fields of muscle and neurophysiology, and from 1892 to 1903 he regularly spent many months of the year in Naples at the famous Zoological Station of Anton Dohrn (1840-1909).

Uexküll adapted the methods developed by Kühne for frogs to the investigation of marine animals. He aimed to reveal the principles underlying the muscular movements and reflexes of sea urchins, brittle stars, peanut worms and octopuses. He designed several devices for the observation and recording of the physiology and behaviour of animals (Mislin 1978). In 1899 he went to Paris to study in the laboratory of the physiologist Etienne Jules Marey (1830-1904), the master of the "graphical method" for the recording of body movements and one of the pioneers of the cinema. Marey had constructed a camera for chronophotography that produced the first short "movies" of moving animals. Uexküll bought himself a camera and used the chronophotographic method for studying the details of, for example, the movements of starfish and the flight of dragonflies and butterflies. 
Together with his colleagues in Naples, Albrecht Bethe and Theodor Beer, Uexküll produced an influential paper (Beer, Bethe, Uexküll 1899) that attacked the use of anthropomorphic terminology in sensory physiology and proposed a new "objective" terminology, substituting ,for example, seeing with photoreception or smelling with stiboreception. This paper turned out to have a broad impact on the development of behaviourism in the US and on the reflex concepts of Pavlov and Bekhterev in Russia (Harrington 1996: 42).

After a conflict about his application for a position at the Zoological Station, and the rejection of this by Dohrn, in 1903, Uexküll went to marine research laboratories in Berck sur mer, Monaco, Roscoff and Biarritz. He married the German countess Gudrun von Schwerin. Their daughter Dana and sons Thure and Gösta were born in 1904, 1908 and 1909.

In 1907 Uexküll was given an honorary doctorate by the University of Heidelberg for his studies in the field of muscular physiology, especially for his discovery that excitation is facilitated to flow towards the stretched muscle (Uexküll 1904a; 1904b). This finding, known as Uexküll's law, proved to be useful in orthopaedics (Kull 2001: 5). In 1913 Uexküll applied for the post as head of the newly founded Kaiser-Wilhelm-Institute for Biology, but he was rejected by most of the biologists there (Sucker 2002: 136-151). But with the help of influential persons on the board of the Kaiser-Wilhelm-Gesellschaft, Uexküll's idea of establishing a "Flying Aquarium" was supported with 10,000 Marks. Having been used to carrying his equipment from place to place, Uexküll had developed concepts and devices that allowed him to do research outside the established institutions and without a fully equipped laboratory. According to his plans the aquaria of zoological gardens all around Germany could house small laboratories that would give the opportunity for occasional scientific research on a great variety of subjects (Sucker 2002: 136f). But with the beginning of World War 1 such plans lost priority.

\section{World War One and political publications}

Uexküll did not restrict himself to scientific publications. He expressed his active engagement in the social and political sphere in 
the media. This revealing public engagement has to be described in the context and under the significant influence of the First World War.

Before WW1 Uexküll had only published in the general interest press to popularise biology and his ideas about it. During WW1 and its aftermath, he started to write articles on political and social matters as well, and produced nearly 100 popular pieces on politics, morals, and spirituality before his death. The beginning of WW1 was greeted by Uexküll with patriotism. He and his family stayed on a family estate in Pomerania. As Balts they had Russian passports, but they were received well in Germany. Uexküll ascribed holy ideals to the German family, which for him was the true elementary unit of the nation. In 1915 under the title "Volk und Staat" he wrote in the magazine Die Neue Rundschau:

Why did even foreigners staying in Germany have the impression that this war was a holy war? Because German family life suddenly revealed itself before all the world, because the holy fire of idealism that had illuminated and warmed individual homes shot up toward heaven like a single mighty flame. (Harrington 1996: 55)

Uexküll hailed idealism as a holy feeling for unity and responsibility, which, according to him, were the fundamentals of harmonic national association. And he ascribed this idealism mainly to a German type. This ethnocentristic is well documented in his correspondence with the philosopher and writer Houston Stewart Chamberlain (18551927). Uexküll was deeply disappointed when England, supposed to be a Germanic nation, sided against Germany. In a letter to Chamberlain on August 11, 1914, he wrote:

How does England come to make common cause with these culture-hating bandits? Genuine human culture can be sustained only through England and Germany together. (Harrington 1996: 55)

The Englishman Chamberlain had become a German by choice. He had studied physiology and biology, turned to philosophy and married Richard Wagner's daughter Eva. He won the friendship of Kaiser Wilhelm and later that of Adolf Hitler. The relationship between Uexküll and Chamberlain, especially the fact that Uexküll edited Chamberlain's book Natur und Leben (1928) was often taken as an argument to prove a close connection between Uexküll and Nazi- 
ideology. When trying to understand the development of Uexküll's worldview, one has to see his life in its context and have a closer look at the relationship to Chamberlain. The Uexküll-Chamberlain correspondence has been analyzed by Schmidt (1975) and she describes some of the anti-semitic sentiments shared by the writers. But Schmidt also cites from a letter that Uexküll wrote to the widow of Chamberlain in 1933: "Not purity of race, but purity of ideas, Chamberlain demanded from the Germans" and Chamberlain's motto could be summarised as " reverence for the personality, be it arian or Jew, is the highest Demand" (Schmid 1975: 127). Though Uexküll tried defend Chamberlain from Nazi-protagonists claiming him for their movement, and though Hitler and his clique were not sympathetic to him, the Baltic aristocrat blamed the parliamentary system for the crisis in Weimar Germany and as many German conservatives saw a last hope in Hitler. In the second edition of Staatsbiologie Uexküll expressed his aspiration that Hitler would save Germany from the avarice of international capitalistic forces. (Uexküll 1933: 78)

The nationalistic mindset of Uexküll had developed during WW1. In 1914 Uexküll urged Chamberlain to call on his countrymen to support Germany, but like many Germans Uexküll changed his mind quickly when England failed to come to its senses. The English and their culture became his main target, his object of contempt, to whom he projected all his dissatisfaction with the state of development of human relations. Here he found the opposite of his ideals. In the English mind he discovered "an irresponsible consciousness" which he identified to be the counterpart of the German Gewissen, that made the Germans so superior in matters of morality. Uexküll expanded his critique of Darwinism from biology to politics. In his article "Darwin und die englische Moral" of 1917, on more than 25 pages Uexküll declared Darwin's doctrine to be ungrounded and false, but he said it reflected very much of Darwin's own thought about the behaviour of his fellowmen: Darwin truly describes their inferior morals and their brutal market ethics. Uexküll concluded:

The German imperative of Kant requires every individual to be an autonomous lawgiver on moral issues. In contrast, Darwin exonerates the individual from this responsibility with his English imperative. [...] Darwin's position can be briefly summarised in the following way: the bigger the herd, 
the higher the morality) [...] From the English character, there is no way to pure humanity — but many ways to its opposite. (Uexküll 1917: 229)

Uexküll gave examples to demonstrate how cruelly and irresponsibly the English had treated the people under their rule; e.g., that they let starve to death one million people in Ireland and nineteen million in India. These acts of cruelty could, according to Uexküll, never be performed or tolerated by their ideal counterpart, the Germans; his sons would learn how much their father had erred in his blind nationalism.

Uexküll concluded that the English expand their capitalistic system and use their monopolistic trade in order to force the rest of the world into slavery. He even accused the British of being so cunning as to make the world blame the Jews for the results of British politics. According to him, this was possible because England dominated international public opinion with its newspapers and was able to extend its influence into all countries who had adopted parliamentary democracy. Thus, parliamentary democracy, "the rule of the crowd", was the dangerous foe of real democracy which could be established only by German idealism (Uexküll 1917: 242),

The alliances of the western democracies, and most of all that of America with Russia, whose medieval methods, not least concerning the Jews, seemed to be amoral to Uexküll. He wrote: "Thousands of Jews are being tortured and burned in Russia. That is well known in America, but they continue their dirty trade of arms with Russia." (G. v. Uexküll 1964: 101)

After the war had begun to drag on and its disastrous consequences had become clear, Uexküll came to see hope only in biology. The poet Rainer Maria Rilke, who had been a friend of the Uexküll family since 1904, turned to the scientist in 1917 to take some lessons in biology. Rilke wanted to find relief from his depression in the science of organic life and its harmonic. Uexküll reassured Rilke's notion, that a new era was near and went on:

The war of minds has begun.[...] in this battle biology will be the leader, because she has to fight with physics and chemistry, who up to now have filled the armoury of man. (G. v. Uexküll 1964: 123)

Later, in 1921, after his Theoretical Biology had been published and well received, Uexküll wrote to Chamberlain: "I have noticed that the 
biological mode of expression is more attractive to our contemporaries than the abstract philosophical" (Harrington 1996: 56).

Uexküll had recognised that the language of biology helped him to popularise his views of law and order in politics. It gave him powerful metaphors to naturalise his worldview in the general interest press.

During WWI and the Russian revolution the Uexkülls and other Baltic-Germans lost most of their property in the Baltic states, which they had hoped would be annexed and integrated into the Reich. Uexküll compared the German republic to a corrupt organism that accepted its own dismemberment. He described the turmoil in Russia following the October revolution of 1917 as the deterioration of a giant amoeba into a blob of rotting protoplasm. As early as November 20th 1917 he wrote in a letter to Chamberlain:

In Russia the long awaited moment has come, the protoplasm of the giant amoeba is fully in the process of decomposition, and it is no longer possible to stop this natural process. Senseless pillage and murder are on the increase [...]. (Harrington 1996: 57)

With the end of the war and the defeat of Germany foreseeable, Uexküll became more and more convinced of the necessity of a strong state. Only this could, according to him, stop the "putrefaction of the nation". The holy idealism of the German family seemed to be destroyed, and bereft of their elementary relations the individuals were no longer able to autonomously associate into a harmonious political organism. The greed of the masses to seize power had to be restricted by a mighty government. He worked out a whole metaphoric description of society at large, his Staatsbiologie, Biology of the State (Uexküll 1920b).

After he had lost most of his possessions during WW1 and the Russian Revolution Uexküll could no longer pursue his research in the far off laboratories in France and Italy. But the restrictions might have helped to bring Uexküll to sift through and summarise the results of many years of work and in 1920 his Theoretische Biologie was published. In 1921 the thoroughly revised edition of Umwelt and Innenwelt der Tiere was published by Julius Springer. In 1924 Uexküll's 60th birthday was celebrated by his disciples and friends with the publication of a jubilee edition of Pflügers Archiv für die gesamte Physiologie (Bd. 205) containing 19 papers of authors from all over the world. But still Uexküll yearned to see the fruitful 
development of his ideas put into action in practical research. His art of experimenting, investigating and observing could find continuity only in a laboratory supervised by himself.

\section{Realisation of an institution and an intellectual school in Hamburg}

In 1913 Otto Cohnheim (1873-1953), who had admired Uexküll ever since he had been supervised by the latter in Naples and Heidelberg, had been called to head the Physiological Institute of the Eppendorf Hospital in Hamburg. Cohnheim became famous for his research on enzymes, respiration and the physiology of UV-light. He changed his Jewish name into Kestner in 1917. In 1919, when the University of Hamburg was founded and the hospital in Eppendorf became an institution within the university, Kestner became Ordinarius of physiology. In this position he was allowed to nominate people for the Nobel Prize and he did not hesitate to suggest Uexküll twice. Kestner also used his good contacts to the administration of the university and the head of the zoological society in Hamburg to find his teacher a place.

The old zoological garden in Hamburg, which had been founded and headed by the famous Alfred Brehm (1829-1884) from 1863 to 1866, had suffered during WW1 and the period of inflation in Germany. It could no longer compete with the new zoo of Carl Hagenbeck (1844-1933). However, it was decided to keep some of its attractions. One of them was the aquarium, which had been built in 1864 under the supervision of William Lloyd. Lloyd had constructed the aquarium at the London world fair exhibition. By introducing new architecture, illumination and technologies he helped to sustain temperature and water quality and made the aquarium more attractive to the public. After having built the aquarium in Hamburg he went to Naples to build the aquarium inside Dohrn's station.

In the 1920s the aquarium in Hamburg had been neglected for years and needed to be revived. Cohnheim suggested that Uexküll was the right man for the job and Uexküll got his first paid position as scientific assistant in charge of the reconstruction and reorganisation of the aquarium. Moreover, he was given the opportunity to use the aquarium as a research station. Starting a Laboratorium für Umweltforschung in a kiosk adjacent to the aquarium in 1925, Uexküll managed to found the Institut für Umweltforschung in 1926. The institute flourished into a vital research centre and until 1934 produced 
more than 70 papers under the direct supervision of its head (Kühl 1965; Hünemörder 1979). Konrad Lorenz visited the institute in the 1930s and dedicated his monograph "Der Kumpan in der Umwelt des Vogels" (Lorenz 1935) to Uexküll.

\section{Intellectual "Umwelt" in Hamburg}

The University of Hamburg was not one of the old established institutions. Founded in 1919 with democratic aspirations in the young German Republic it soon became known for its liberal spirit and for the support of unconventional and interdisciplinary scientific developments. It gathered a circle of scholars that became very influential for the development of 20th century thought. The Philosopher Ernst Cassirer (1874-1945) had founded the Philosophical Seminar and became head of the university in 1929. Elaborating his neo-Kantian ideas, Cassirer looked for the foundations of epistemology and his ideas belong to the classics of semiotics. His Philosophy of Symbolic Forms (1923-1929) was meant to found a theory of meaning to understand the creation of reality by human culture. Cassirer made himself familiar to contemporary psychological and neuro-physiological research and was closely connected to the Psychological Institute of the university founded and headed by William Stern (1871-1938). According to Uexküll's wife, in 1931 Cassirer commented on a lecture which Uexküll had given at the Congress of German Psychologists. Uexküll had described how dogs claim their territories by putting down scent marks. Cassirer reminded the audience that Rousseau had condemned to death the first man who had erected a fence and claimed the territory for himself. Cassirer explained that after the Uexküll's lecture it had become clear that this execution would not have been sufficient - in order to prevent privatisation, the first dog would have to have been killed. The same lecture of Uexküll had provoked another kind of scholar. Josef Goebbels, later Hitler's Minister of Propaganda and Culture, wrote an article that described Uexküll as a representative of the German professors who follow ridiculous occupations instead of giving the German Volk a feeling for its "real responsibilities" (G. v. Uexküll 1964: 168f).

In the second chapter of his "Essay on man" (1944), entitled "A clue to the nature of man: the symbol", Cassirer referred to Uexküll 
and his description of the functional cycle as a clue to the understanding of meaning in biological terms. But he came to explain that man by developing a symbolic system inside the cycle is more detached from nature than animals, and is by this qualitative innovation to be distinguished from animals (Heusden 2001).

Cassirer worked in the Psychologische Institut of the University of Hamburg in close cooperation with William Stern (1871-1938), who had taught in Hamburg since 1916 and was one of the universities founding fathers. Stern developed his "Differentielle Psychologie" (1911), as an attempt to integrate biomedical sciences into the philosophical, ethical and social framework of contemporary psychology. The epistemological approaches at his institute centered around the concept of the person and his subjective experience. New experimental methods were established and the laboratory of the Institute was built up consequently. Stern's coworker Heinz Werner (1890-1964) became famous for developing an organismic approach to developmental psychology and language which tried to counter the "geometic-technical model of communication". Werner put forward an integrating model of human perception, development and meaning in language (Nehrlich 1992). In the second edition of his book Einführung in die Entwicklungspsychologie (Werner 1933: 39), Werner refers to the latest experiments performed in cooperation with Uexküll's laboratory, especially the work of the psychologist Emanuel Sarris on the dog's ability to understand human language (Sarris 1931; in Uexküll's Nachlass several offprints and Werner's Einführung in die Entwicklungspsychologie (1926) with dedications to Uexküll document the contacts between the scientists).

A closer alliance developed between Uexküll and the philosopher and historian of science Adolf Meyer (1893-1971) or Meyer-Abich as he named himself after 1945, after adding the name of his wife to his, who was a prominent representative of holism in Germany. He had studied philosophy in Göttingen with Edmund Husserl (1859-1938) and in Jena with Rudolf Eucken (1846-1926). He came to Hamburg in 1921 to take care of the natural sciences at the State- and UniversityLibrary. In 1925 Meyer-Abich was the first to get an interdisciplinary Habilitation for "Philosophie der Naturwissenschaften und Geschichte der Naturwissenschaften" in Germany. Following the Neokantian trend of the time, his thesis Logik der Morphologie was a critique of biological epistemology. After getting acquainted with the 
work and person of Jakob von Uexküll and Hans Driesch (18671941), who had been born in Hamburg, Meyer in his second monograph Ideen und Ideale der biologischen Erkenntnis (1934) treated the conflict between vitalists and mechanists. Together with Uexküll, Meyer gave a number of seminars on the philosophy of science. Meyer-Abich taught in Hamburg until 1969 and became one of the founding fathers of the Institute of the History of Science (Institut für Geschichte der Naturwissenschaften, Mathematik und Technik), which today looks after the Jakob von Uexküll Archive. In spite of the apparent success and creativity of the Institut für Umweltforschung, Uexküll had to struggle hard for the survival of the institute for several reasons. He himself was beyond the regular age of retirement. His chair was essential for the institute, but only his reputation could convince officials to prolong his employment. The established zoologists questioned the legitimacy of Umweltforschung and refused to examine Uexküll's disciples. Many of them went to the university of Kiel instead, where animal psychologist Wolfgang von Buddenbrock (1884-1964), Ordinarius of zoology until 1936, and his successor Adolf Remane (1898-1978) acknowledged the discipline of Umweltforschung. Uexküll and his assistant Friedrich Brock (18981958) had to fight hard before Brock, after his habilitation in Kiel in 1938 , could be nominated successor to Uexküll in 1940. Uexküll, aged 75, set off to retire on the island of Capri, but went on discussing and propagating scientific and philosophical aspects of his approach to biology. Some of his unfinished bio-philosophical works could be published after Uexküll's death in 1940 by his widow and his son Thure (Uexküll 1944; 1947; 1949; 1950).

\section{Scientific survey}

Biology as epistemology

Uexküll's ideas decisively contradicted the mainstream of thought in 20th century science. When confronted with his writings, it helps to remember their history and to recognise the central theme of Uexküll's scientific agenda: his philosophy of science and his concern for creating foundations for a renewed integration of biology and epistemology.

In the modern era, physical science attained a dominating role as a model for the production of all knowledge. The ideal of positivist 
objectivism was shaken before the turn of the 19/20th century, but, despite the findings of Einstein and Mach, biologists grounded their young science on mechanistic concepts and attempted to resurrect scientific realism in the fin-de-siécle world of increasing relativism. This conception of biology and epistemology was challenged by the physiologist Uexküll. He turned against objectivism and offered a subjectivist epistemology based on biology. His main concepts aimed to re-introduce the autonomous organism as subject into the life-sciences and at the same time to make subjectivity the object of the scientific method. Uexküll pointed out that all scientific investigation is an act of human subjects, ruled by biological processes not sufficiently explicable by physics. Thus, biology, not physics, should be the basis of all science. Uexküll focused on meaningful responses which enable every organism, humans included, to actively realise its own life-world — it's unique Umwelt. Consequently, scientists were subjects interpreting and constructing their objects. Besides this refutation of scientific objectivism, Uexküll's concept of the universe as the creation of countless individual Umwelten challenged the idea of one universal objective world. Refuting reproaches of solipsism, Uexküll did not deny the existence of a physical world, but rejected the claims of its universally equal intersubjective significance and labelled them "metaphysical", However, Uexküll emphasised that intersubjective (interspecies) understanding is the central aim of biological investigation. In his research, called Umweltforschung, he explored the creation and interplay of the unique life-worlds of animals and independently developed an approach, labeled posthumously as "cryptosemiotic" (Sebeok 1979). This biology, conscientious of its subjectivity and the interdependence of organisms, provided him with arguments against the modern worldview, which he saw as being misguided by anthropocentrism, speculative Darwinian theories and the misuse of machine analogies.

Uexküll's concepts were based on empirical physiological studies of the movements of invertebrate animals and developed under the influence of Kant's philosophy.

\section{Physiology, biology, Umweltforschung}

Disappointed by his teachers' speculative views on biology Uexküll found his field of mastery in physiology, especially of invertebrate animals. But he went on to broaden the scope of the science of living 
matter and did not give up trying to save the science of biology from the fundamental errors which he saw within it. In his first monograph Uexküll (1905a) had already assigned different roles to physiology and biology. Physiology should organise the knowledge about organic systems by looking for causalities. Having preserved the advantage of the experimental method, physiology should help to renew biology. In contrast to physiology, biology should empirically go beyond the investigation of causalities by exploring the laws that ensure the purposefulness (Zweckmässigkeit) of living matter. Therefore biology should study organisms not as objects, but as active subjects. This would mean a shift of focus onto the organism's purposeful abilities that enable its active integration into a complex environment. Biology therefore had to deal with holistic units and to maintain a broader scope than physiology in order to grasp the interactive unity of the organism and the world actively realised by it. In order to describe this unity, Uexküll introduced the term Umwelt (Uexküll 1909). Umwelt as a term and concept became most significant in $20^{\text {th }}$ century thought and it is on account of it that Uexküll is most frequently cited in contemporary literature (Sutrop 2001). In Umwelt und Innenwelt der Tiere (1909) he introduced the term Umwelt to denote the subjective world of an organism. For him Umwelt was the unique phenomenal world embracing each individual like a "soap bubble". He stressed, that the individual organism is always actively creating it's individual Umwelt and that this creative process is related to meanings determined by the animal's internal states, needs, design (Bauplan) etc. These interrelated factors that determine the process of the creation of Umwelten were the subjects of the scientific investigation called Umweltforschung.

\section{The discovery of negative feedback control in organisms}

At the beginning of the 20th century, Uexküll recognised the important role of negative feedback control in organisms. He used the concept of the Funktionskreis (functional cycle) to illustrate behaviour as a regulated process. Uexküll's models can be seen as the predecessors of cybernetic models. Recently Uexküll has been discussed as a pioneer of cybernetics and artificial intelligence studies (Lagerspetz 2001; Emmeche 2001; Roepstorff 2001).

In 1904 Uexküll formulated a law of neuro-motor regulation (Uexküll 1904a; 1904b). Uexküll's law stated that 'nervous excitation always flows towards the stretched muscles'. This law helped to 
explain how muscular tone and position maintenance is regulated in animals. Uexküll findings were useful in orthopaedics (Haupt 1913; Wieser 1959). The finding that the activity of the nervous system facilitates the contraction of stretched muscles and thereby counteracts and regulates the stretching of muscles can be considered to be the first formulation of the principle of negative feedback inside living organisms. In his Theoretische Biologie Uexküll developed these early cybernetic ideas and used little diagrams to illustrate them (Fig. 2; Uexküll 1920a: 201; 1928: 209).

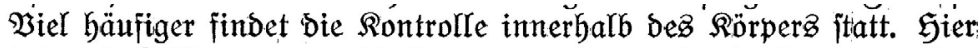
jino 3wei Srälle $3 \mathfrak{u}$ unterjheiden: entweder wird bie Bewegung Der (Effeftorenmużeln Durd) bejondere jenjible Terben rezipiert, wie daz beifolgende Shema zeigt. $>\mathrm{C}=\mathrm{O}$ ober es wirb bie ben effef= torifa)en Terven übertragene Erregung Durch bejondere zentrale Rezeptoren 3um Teil aufgefangen und Dem Werforgan 3ugefübrt. $>Q=\mathrm{O}_{\longrightarrow}$ Dieje Rezeptoren bilden Daz zentrale Ginnesorgan von Selmbolb, Daż anatomijd nod) völlig im $\mathfrak{D u n f e l n ~ l i e g t . ~}$

Figure 2. Little diagrams in the text illustrating a description of feedback and reafferent control (Uexküll 1920: 201).

These figures already show the now familiar outline of feedback loops and may be seen as their early graphical representations before the science of cybernetics had been inaugurated. However, Norbert Wiener developed his ideas in the 1940s, when he was working on servomechanisms for anti-airplane guns and compared problems of automatic-steering mechanisms to problems of neurology in order to explain failures in goal directed movements, which Arturo Rosenblueth had presented to him (Rosenblueth et al. 1943; Wiener 1948; Lagerspetz 2001).

As one can read in the text to Fig. 2, Uexküll postulated that there are two ways that information about muscle movements is fed back into the afferent side of the nervous system: (1) from receptors for the movement of the muscles (hypothetical movement- or stretch receptors), (2) from central receptors ("das zentrale Sinnesorgan" of Helmholtz) that take up a part of the excitation sent to the efferent nerves and make it available to information processing in the afferent 
net of nerve cells. This second control principle was inaugurated by Holst and Mittelstaedt at the end of the 1940s as "Reafferenzprinzip" (Holst, Mittelstaedt 1950).

Overcoming the reflex-concept by the functional cycle

Since his early work on the movements of the brittle star in 1904, Uexküll had tried to work out a more general concept to explain the control of behaviour in moving animals. By developing the functional cycle Uexküll tried to extend the concept of the reflex arc. In the second edition of Umwelt und Innenwelt der Tiere, Uexküll replaced the chapter on reflexes written in 1909 with a chapter on the functional cycle (Uexküll 1921). A section about "Die Funktionskreise" had already been included in the first edition of Theoretische Biologie (Uexküll 1920a). Uexküll had illustrated his description of the new concept with little schemes inside the text (Uexküll 1920a: 116-117; Fig. 3, 4.) Most notably, Uexküll already had described the principle of reafferent control by feedback of motor commands and graphically represented it in another early scheme (Fig. 3): an inner cycle, "Neuer Kreis", stands for a connection within the nervous system, which ensures the direct flow of information from the Handlungsorgan, which generates the impulses for the effectors to the Merkorgan, which is processing it together with information from the sensory system. Uexküll already recognised that this embodied self-reference not only serves to control movements, but is a central prerequisite for a coherent perception of the world (Uexküll 1920a: 117). The enduring relevance of this idea can be seen in its place in current neuro-scientific concepts of embodied cognition (Kelso 1995; Rizzolatti et. al 1997).

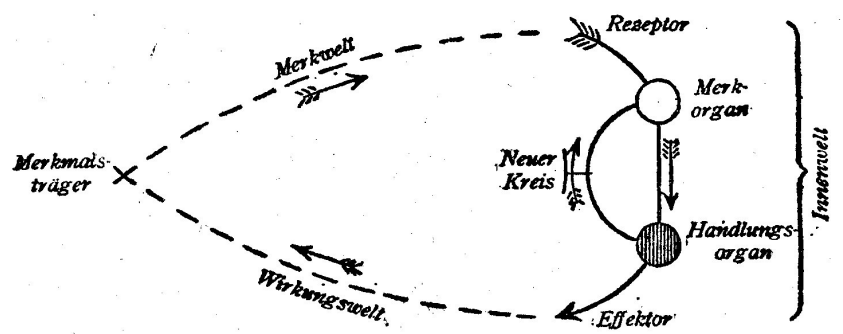

Gigux 4.

Figure 3. Functional cycle with reafferent cycle (Uexküll 1920a: 117). 
According to Uexküll, the modelling of functional cycles should help to conceptualise the functional organisation of behaviour as an ongoing process of regulation. It represents the animal organism as a subject that is integrating objects into its Umwelt: this process is depicted as a closed loop of interactions. A modern description of the ongoing process in English terms was tried by Figge (2001). The following attempt uses his terms and some of the terminology introduced by Urmas Sutrop in Fig. 4.
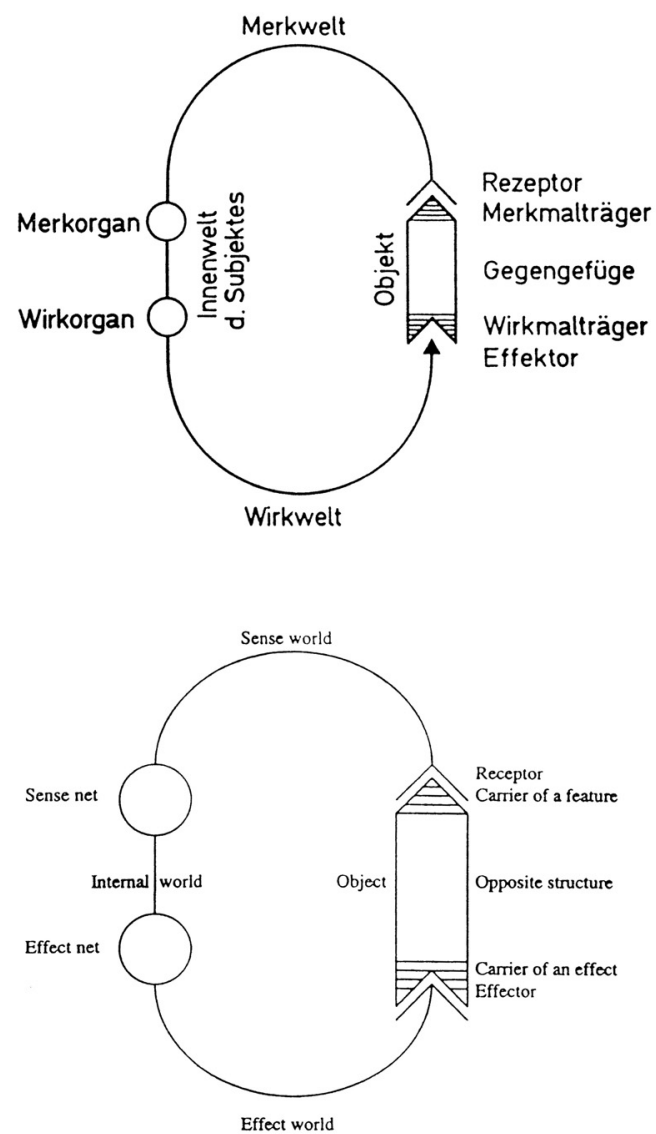

Figure 4. Funktionskreis or functional cycle with German and English terms (Uexküll 1921 and Kull 2001, translated terms by Urmas Sutrop). 
The organism's nervous system is equipped with receptors and sense nets (Merkorgane), effectors and effect nets (Wirkorgane). The sense net is able to discriminate and represent particular features of the organism's Umwelt. The representation produced by a distinct receptor unit is called Merkzeichen, which can roughly be translated as "feature sign". The effect net is tuned to produce muscle impulse patterns and to stimulate effector cells thus producing an effector sign (Wirkzeichen). If a particular quality of an object in the organism's Umwelt stimulates the cells of the peripheral receptors, the corresponding sense net produces a feature cue (Merkmal) for the object, which is assigned to its original feature display on the object (Merkmal-Träger). The sensation, for example, of a huge green shade in the sense net is processed together with simultaneously produced feature-signs indicating space and time (Lokalzeichen, Momentzeichen) and recognised as a perceptual cue, which is assigned to a tree outside. The effect net is connected with specific peripheral effectors. The activation of specific cells of the effect net orchestrates the cells of peripheral effectors, and when this effector acts upon an object, then the effect sign (Wirkmal) as a functional cue is displayed on or by the object (Wirkmal-Träger). The functional cue effected on the object transforms the state of perception of this opposite structure, thus erasing the original cue. This change leads to the perception of a new cue which starts a new cycle of sign production, which is attuned according to feedback and reafferent input or by other signs within the internal world of the organism.

Uexküll used the interaction of the female tick with a mammal to exemplify his description of behaviour as a pre-designed chain of interconnected functional cycles (Uexküll, Kriszat 1934: 7). The glands on the skin of mammals are carriers of the feature (Merkmalsträger), butyric acid, which stimulates the tick's receptor cells. The corresponding sense net produces a feature sign (Merkzeichen), which is used as a cue (Merkmal), assigned to the mammal. The central processing in the sense net induces (and Uexküll stressed that it was not known how) the corresponding structures of the effect net, innervating the muscles of the tick's legs: the tick detaches herself from the twig she is hanging on and lands on the mammal, thereby putting an effector cue onto the hairs she is touching. The hairs are thus carrying the feature for the next cue received and turned into the feature cue of hairiness, which is assigned to the mammal and at the 
same time has "erased" the olfactory sign, so that a new cycle has started. The cue of hairiness induces the effect web to orchestrate the movements for crawling through the mammal's hair until the tick reaches bare skin, which "erases" the cue of hairiness and leads to the perception of the thermic cue of body temperature which induces the movements of drilling into the skin, where blood is the cue for the next cycle of sucking. Internal receptors produce signs of saturation that induce the tick to leave the skin, to drop, and to lay her eggs.

The example of the tick was advantageous because just a few cycles are needed to describe the ticks behaviour and because experiments had revealed that a few cues (butyric acid, hair and body temperature) were sufficient to induce the corresponding behaviour and link one cycle to another. Uexküll said that the Umwelt of the tick was simple or "poor" in comparison with the Umwelt of mammals, but "poverty" of the Umwelt is a prerequeisite for the ensured success of the ticks behaviour (Uexküll, Kriszat 1934: 8).

\section{Umweltforschung in action - some examples}

The researchers coming to the Institut für Umweltforschung of the University of Hamburg came from different faculties of science and often brought their subjects with them so that the works produced were very heterogeneous. There was no model organism and the subjects covered a broad range of scientific questions. There were works on the physiology of muscles, sense organs, body movements and works on different aspects of behaviour and communication in animals, performed with different animals from cockroaches to snakes to dogs. Since the institute was founded as part of the aquarium of the zoological garden, and Uexküll was a specialist for the behaviour of marine animals, these were among the first subjects to be investigated.

\section{Sensory physiology - the basis for "Umweltforschung"}

Thure von Uexküll explained: "The approach of Umweltforschung aims to reconstruct creative nature's process of creation". It can be described as "participatory observation". "This method of observation, in the sense of Uexküll [...] means first of all ascertaining which of those signs registered by the observer are also received by the living being under observation" (T. v. Uexküll 1987: 149). Essential for this 
was the investigation of the capacity of the sense organs. Sensory physiology had to pave the ground for further research into the problem of access to the Umwelt of animals. This basic research could only reveal a first outline of the realisable Umwelt of the animal. However, by investigating the animal's ability to perceive and discriminate different physical stimuli, Uexküll tried to get initial indications of their significance for the animal's behaviour — first ideas about the signs that possibly constitute the animal's Umwelt. For Uexküll this was the basic methodology to analyze the "subjective space" (der subjektive Raum) of the animal (Uexküll, Brock 1927; Uexküll, Kriszat 1934).

Uexküll and his assistant Friedrich Brock tried to give the reader a vivid demonstration of the results of basic Umweltforschung in the new laboratory and published illustrations of the different Umwelten of different living beings (Fig. 5). Normal photographs presented the human Umwelt. By using grids with different pitches of the matrix, the resolution of the compound eye of a fly (Musca) or the eye of a mussel (Pecten) was emulated. The pitch of the raster was corresponding to the frequency of sensory elements within the eyes of the animals. These dots were called "Sehorte" — visual locations in the visual space. In order to eliminate the artifacts of the grid, aquarell paintings of the supposed Umwelten were produced. However these peaces of art were based on scientific grounds and were later reproduced in the famous Stroll through the Umwelten of animals and humans (Uexküll, Kriszat 1934). The pictures helped to make conscious to the reader how differently humans and animals perceive the world they share. They thus served as a method for intersubjective and interspecies understanding - as the first fascinating steps into the Umwelten of other organisms. 

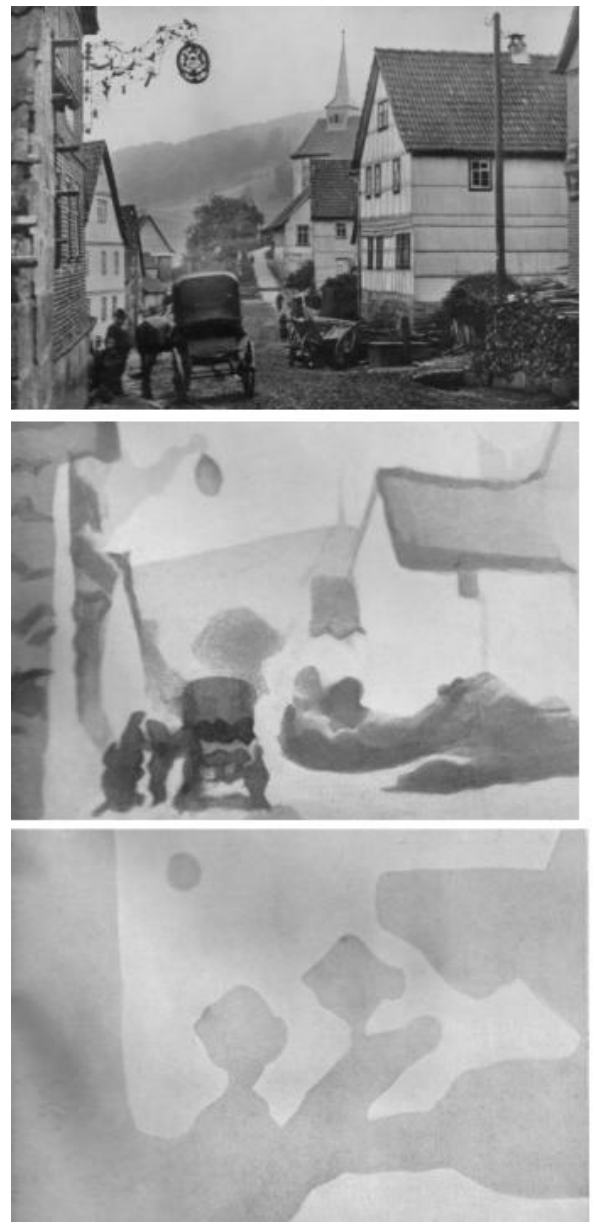

A street in a town, seen through the eyes of a human

The same street seen with the eyes of a fly

The same street in the eyes of a mussel

Figure 5. Illustrations of the different visual Umwelten of a human, a fly and a mussel (Uexküll, Brock 1927).

Uexküll explained that the optic world is constructed out of elementary units that correspond to the sensory cells. The cells' position in the eye corresponds to the site in the optic space (Sehraum) and in his cryptosemiotic language he talked of local signs (Lokalzeichen). The number of receptor cells limits the number of sites and thus the amount of, or complexity of, signs to be perceived. 
Thus it can be predicted that the complexity of the optic sense world (Merkwelt) of the snail or fly is much smaller in comparison to the human visual space. Uexküll exemplified that this was the reason why a fly could not detect a spider's web before it was trapped (Uexküll, Kriszat 1934: 21).

\section{The Umwelt of the fighting fish}

Hans Werner Lißmann, who later continued his career in Cambridge and became famous for his pioneering investigations on fish electroreception (Lissmann 1951), under Uexküll's supervision started to investigate the behaviour of the Fighting Fish (Lißmann 1932).

In order to identify the physical features that function as signs of rivalry, Lißmann made extensive use of the concept of a dummy. $\mathrm{He}$ could count the attacks that were elicited by dummies with different body marks. He thereby assessed their significance as signs (Merkzeichen) in the functional cycle of rivalry (Fig. 6). Lißmann's method of analysis of behaviour was a forerunner of the famous studies of the behaviour of the stickleback which Nikolas Tinbergen performed some years later and described as a method for the "objectivistic study of the innate behaviour of animals" (Tinbergen 1942).

Lissmann was also a pioneer of the so called mirror image stimulation (MIS) (Rowland 1999). In order to study the specific perception of time, the Moment or Momentzeichen, as Uexküll called it, Lißman used the agonistic behavior of the Fighting Fish Betta spledens. Today we would say, he went to determine the "flicker fusion frequency". Lissmann constructed an ingenious apparatus and conducted an experiment that was hence used to test the perception of time or movement for visual signaling in other species:

By requiring subjects to view their mirror image through evenly spaced slits in a rotating wheel, Lissmann in effect presented subjects with a series of still images in more or less rapid succession. As the male began to 'interact' with its mirror image, Lissmann slowed the wheel until the male ceased to react to its mirror image. At this point the separate views through the slit no longer followed each other soon enough to fuse into a moving image and probably appeared to the fish as a succession of still frames of its mirror image. (Rowland 1999: 291) 

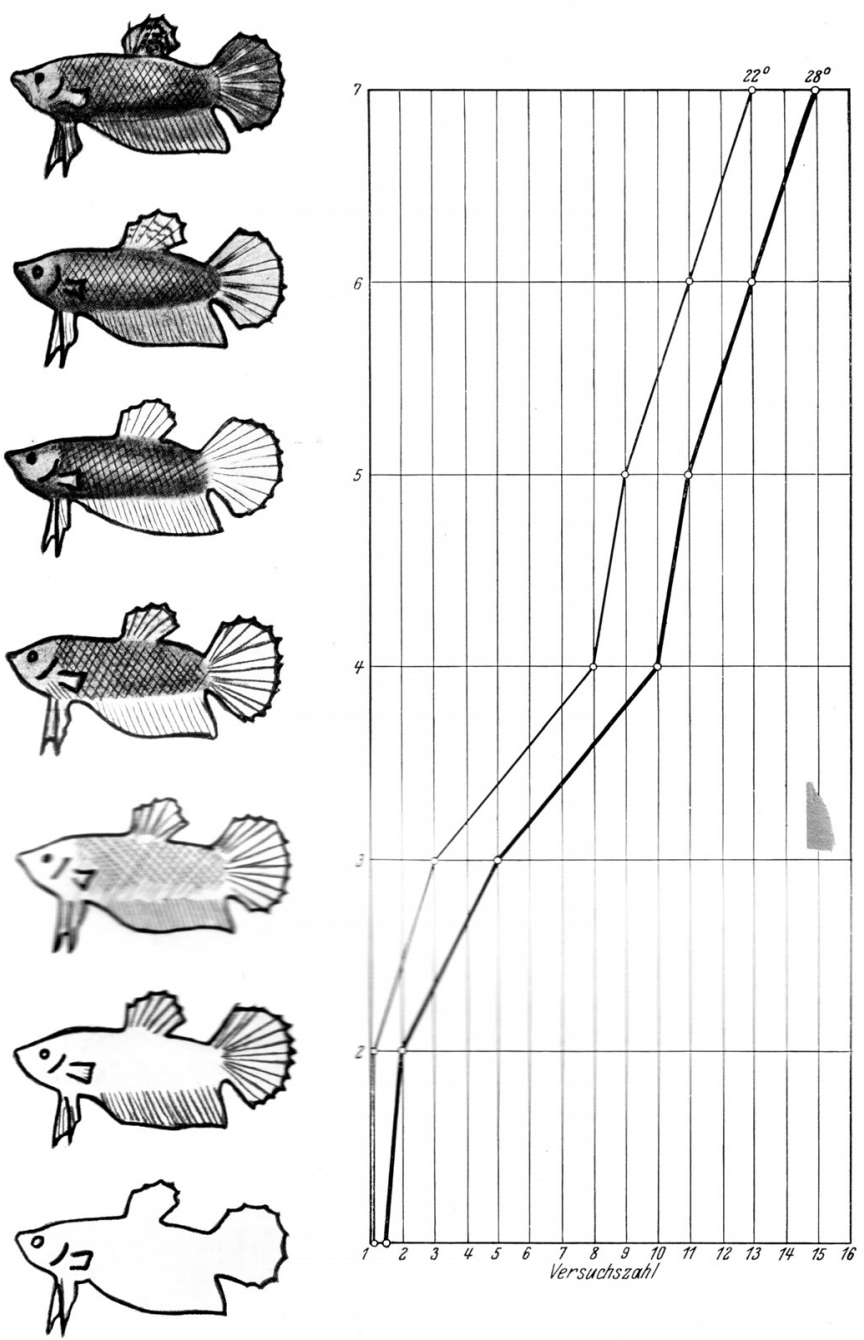

tbb. 8. Bildserie mit steigender Ähnlichkeit. Mit jedem Bild wurden bei $22^{\circ}$ und $28^{\circ}$ je 16 Versuche gemacht (Abszisse). Auf der Ordinate sind die Bilder mit steigender Ähnlichkeit aufzetragen. Die Kurven geben die Anzahl der Erregungen an, die das betr. Bild bei 16 maligem Zeigen beim Kampffisch auslöste.

Z. f. vergl. Physiologie Bd.18.

$6 \mathrm{~b}$

Figure 6. Diagram showing the frequency of aggressive reactions to dummies with different signal cues (Lißmann 1932: 89). 
This method had been developed in the institute in cooperation with Gerhard Brecher. In his Dissertation on the "Development and biological significance of the subjective unit of time" (Brecher 1932) he applied it to humans, snails and, with the help of Lissmann, to the Fighting Fish. The experiments were continued and refined in the institute by Beniuc (1933).

\section{The hermit crab and changes in the significance of a sea anemone}

Friedrich Brock (1898-1959) investigated the symbiotic relation of the hermit crab (Pagurus arrosor) with the sea anemone (Actinia sagartia) (Brock 1927). Brock, who worked in the stations in Naples and on the island of Helgoland, found out that a complex interplay of the two different animals was necessary before the crab could find the right anemone, induce it to leave its place and let itself be planted onto the crab's shell, where it would serve as protector against octopuses, while the anemone would profit from the leftovers of the crabs meals.

Brock tried to identify the specific stimuli that were sent out and interpreted as signs to start specific behavioural acts. His works show that the concepts of Uexküll were very useful as conceptual or heuristic tools for the description of this interspecific symbiotic animal behaviour.

Brock showed that according to the conditions, different interaction schemes could be described as belonging to different functional cycles. The requirements or the needs of the animal were of prime importance for how the crab would interpret the signs emitted by the anemone which then would make it its predominant 'object of desire'.

The results of Brock were also published by Uexküll in the popular Stroll Through the World of Animals and Men (1934) to illustrate the change of meaning in the Umwelt of the subject. Fig. 7 shows three different situations and demonstrates the change of meaning of the sea anemone Actinia to the hermit crab:

(1) Upper row (Fig. 7): if the crab inhabits snail shell without an anemone, an anemone is seen as a welcome partner for symbiosis. The anemone is "hugged" and forcefully persuaded by rhythmic drumming to loosen its hold and then put upon the crab's house.

(2) Middle row: if the crab is naked it will try to use the anemone as substitute for the protecting shell. 
(3) Lower row: if the crab is already in symbiosis with anemones, then it interprets the appearance of another anemone as a welcome prey and starts to feed on the animal.
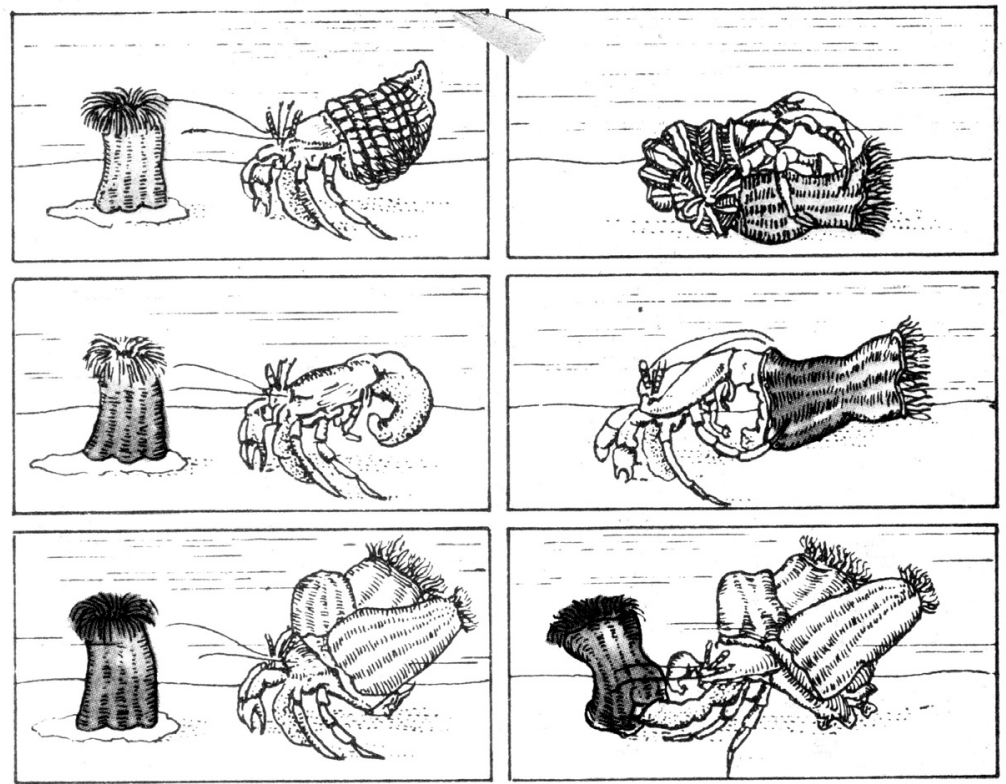

Farbbild 1 Seerose und Einsiedlerkrebs

Figure 7. The interaction of the hermit crab and the sea anemone, changing according to change in meaning (Uexküll, Kriszat 1934: 55).

Brock could show that the significance of the signs emitted by anemones changed according to the crab's needs. The perceived signs are marked with different meanings: depending on the subject's needs they are either made a part of the protection functional cycle or of the food cycle. Uexküll (Uexküll, Kriszat 1934: 55) wrote of the different "tones" of the percepted image (Merkbild) changing with the situational significance. 


\section{Dogs, human language and the effect world (Wirkwelt)}

The last example is the work by Emanuel Sarris (1931), "Sind wir berechtigt vom Wortverständnis des Hundes zu sprechen" ("Can we talk about the dog's understanding of words") which was published in the journal Zeitschrift für angewandte Psychologie. The communication between humans and animals was of special interest to Uexküll and these were the works that came the closest to linguistics in the sense of a semiotic discipline.

Sarris trained his dogs to react to command sentences in two different languages, German and Greek. By reducing the commands to words or just parts of words, Sarris tried to show that dogs understand the meaning of words. The dogs jumped on a chair, when he said "chair". But he also found out that they would jump on a sofa or small table if the chair was not to be seen. With his methods Sarris was able to demonstrate how complex the cognitive and even analytical abilities of dogs are. He stated that dogs could indeed recognise words out of a mixture of sounds and assign meaning to them. "But the understanding of words by the dog is always appropriate to the dog's Umwelt" (Sarris 1931: 126).

When asked about the biological approach to language by the German linguist Heinrich Junker in 1937, Uexküll explained the context in which the experiments of Sarris were to be understood and the meaning that they could have for linguistics:

My main interest in language as a means of communication between man and animal is in connection with the means of communication that animals have among themselves. As means of communication, animals use sequences of movements as well as of sounds, the knowledge of which is innate in animals. [...] Many animals have the ability to distinguish sounds or sequences of sounds as secondary cues of perception - Pawlow could show that dogs, that were accustomed to hearing the sound of a bell before getting food, reacted by salivation already at the sound of the bell alone. Pawlow called this a 'conditioned reflex'. The same effect can be obtained by saying the word 'meat'. Still, from this one cannot conclude that the dog understands the word meat. The experiments carried out by Dr. Sarris at the Institut für Umweltforschung are a different matter. A dog was trained to jump upon a chair at the command 'chair'. When the chair was removed and the command was repeated the dog jumped up on anything a dog could sit upon. We express this as follows: certain objects have for a dog a 'sitting tone'. The word 'chair' for the dog is not the name of a thing [einen bestimmten Gegegenstand] but of a performance [eine Leistung]: to sit. To me this seems a fundamental feature 


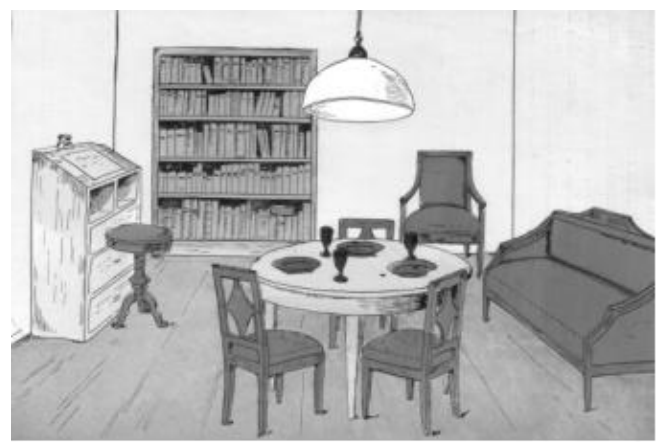

A room as a human Wirkwelt, with objects of a sitting-, an eating-, a dringking and a reading-tone

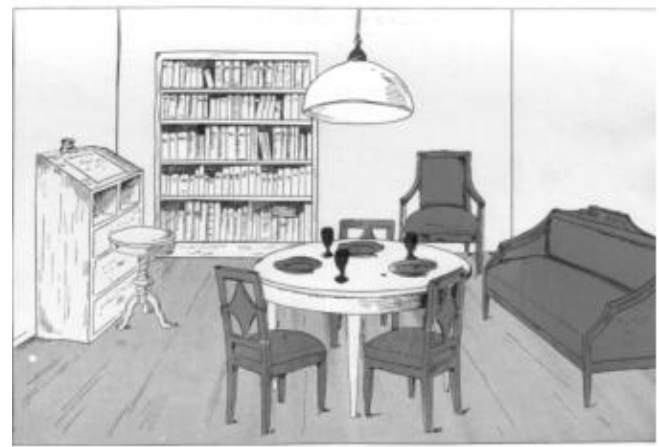

The same room as a Wirkwelt of a dog, showing no reading tone

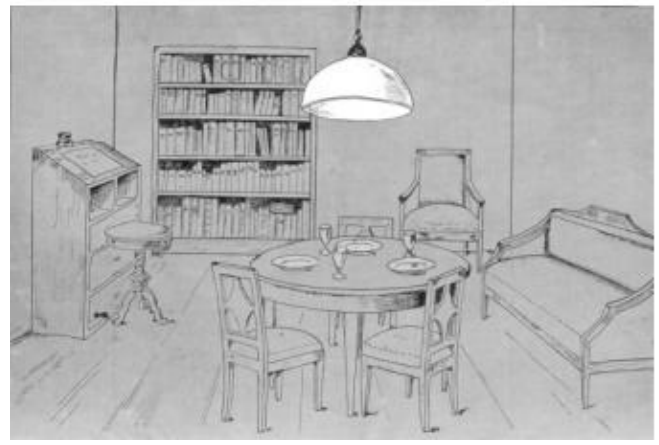

The same room as a flies Wirkwelt, showing even no special sitting-tone

Figure 8. The different Wirkwelten (effect worlds) of a human, a dog and a fly (Uexküll, Kriszat 1934: 56-58). 
of language as a means of communication between human beings as well. The spoken word, a certain sequence of sounds as carrier of sense and meaning, relates primarily to performances and not to things [nicht auf einen bestimmten Gegenstand]. I have taken up the parts of your questions that were closest to me personally. Linguistics proper is far from me - but I am convinced that you are on the right path towards making it a biological science. (Uexküll 2001: 445-446) ${ }^{1}$

In his Stroll Through the World of Animals and Men (Uexküll, Kriszat 1934: 57f) Uexküll used the experiments of Sarris to demonstrate the difference of the Umwelten of humans and animals. He makes clear that the difference is due to the difference in the effect world (Wirkwelt) of animals. The difference of the worlds of a dog, a fly and a human are simply illustrated by three drawings of a room with the furniture and things in it coloured differently according to the different meanings the animals ascribe to the objects - according to the different use the animals and the human make of the objects the objects bear a different "performing-tone" (Wirkton), which is shown as a different colour in the original pictures (Fig. 8).

\section{Concluding remarks}

These examples of the work done in the Institut für Umweltforschung represent just a small part of the diversity of works performed, but they show that Uexküll's Umweltlehre and his Institute provided a roof under which many different researchers, approaches and disciplines could gather and work creatively. Interdisciplinarity was also fostered by the fact that Uexküll's Umweltlehre helped to find a common language. And this language and the approach of Umweltforschung countered contemporary reductionistic trends in the analysis of animal and of human behaviour. These are aspirations that fit well into the objectives of Biosemiotics today (Schult 2004).

\section{Transcending machine metaphors. Uexküll - the first biosemiotician}

It has been shown that the attempt to substantiate Kant's philosophy in biology helped Uexküll to precede the cybernetic approach, the biosemiotic explanation and modern conceptions of cognitive psycho-

German version in T. v. Uexküll (ed.) 1980: 297-298. 
logy. Uexküll had developed his ideas directly from his research on the physiology of movements and the observation of behaviour. His agenda had been to demonstrate the difference between the living organism's autonomous organization and the predetermined mechanisms of the machines of his age. In contrast to Norbert Wiener, who loved to describe biological functions in mathematical terms, Uexküll avoided mathematics and discovered a semiotic language appropriate to embody Kantian philosophy with observations in biology. So Uexküll followed an independent path before the cybernetic approach, and, since his language and methods were developed to explain the fantastic regulation of animal movement and behaviour, it was fruitful in ethology. It allowed Uexküll and his readers to envision a multitude of different functional cycles corresponding to and sustaining the animal within its Umwelt, enabling it to relate to prey, to enemies, to sexual partners, to different objects and media. But it also paved the way for a cybernetic view. With the appearance of the new techniques of computing and the wonderful automatic machines themselves, the acceptance of technical metaphors in biology increased. The emerging image of multiple types of different and interrelated closed control loops could explain body movements and also induced new ways of imagining, illustrating and calculating the complexity of interrelations of organisms and their environment in modern ethology and ecology (Lagerspetz 2001). But it seems that thereby one of the main aspects and advantages of Uexküll's theoretical thinking was left behind the semiotic description and analysis of life.

However Uexküll was a pioneer of the semiotic approach in biology. In 1977 the hungarian-american linguist Thomas A Sebeok (1920 2001) discovered Uexküll to be a "neglected figure in the history of semiotics" and celebrated Uexküll as one of the "Masters of the sign" (Sebeok 1979). Already at the beginning of the 20th century Uexküll had recognised that the fascinating abilities and behaviour of animals are based on sign processes - the perception and transmission of signs onto which meaning is marked according to their significance. He had therefore introduced terms like Merkzeichen, Wirkzeichen, Lokalzeichen, Momentzeichen, and Merk- und Wirkmal.

The special issue of the journal Semiotica dedicated to Jakob von Uexküll in 2001 termed Uexküll "a starter and pioneer of the semiotic approach in biology in the twentieth century" (Kull 2001: 1). The editor stressed the fact that decades before semiotics was applied to 
biology, Uexküll had already commenced studying organisms as subjects at the center of sign processes (Kull 2001; 1999). Uexküll was recognised by Semioticians after his death. After meeting Sebeok, Uexküll's son Thure von Uexküll, a famous physician who had inaugurated psychosomatic medicine in Germany, started to explain his fathers biology as a semiotic concept (Uexküll 1979; 1980; 1981). He stated that "one can truly understand his [Jakob's] terms only, if one sees them on the background of a theory of signprocesses and makes clear to oneself, that Umweltlehre is a science of signs sent and received by living beings" (Uexküll 1980: 292). The recognition of the semiotic character of Uexküll's approach implies the fact that a biologist, who was not familiar with linguistics, Peircean, Saussurian or any other semiotic approach, was able to develop an elaborated terminology and concept for studying sign systems in the animal world. The historical perspective shows that Uexküll developed this approach also as an alternative to the mechanistic and reductionistic trends in biology that he encountered at the beginning of the 20th century.

\section{Uexküll's significance today}

According to Uexküll, biology should focus on the organism's abilities to integrate itself into a complex environment, of which it is a part and which is constantly created by it. He called this investigation of the communicative unity of the organism and the world sensed by it "Umweltforschung". His ideas, terms and models became influential and innovative in the development of science and the humanities in the 20th century. Thure von Uexküll's (Uexküll 1980) interpretation of his father's writings in semiotic terms shows convincingly how the new concept could make biology a meaningful (bedeutungsvolle) science, able to serve as a unifying paradigm for other sciences, like medicine, psychology, economy, ecology and sociology. This Uexküllian interpretation also makes us to acknowledge that our cognition and epistemology are developed in close interdependence with our technological imaginations that have a growing significance in our world. It demands not not to lock up ourselves in these circles of meanings and to open up our senses for the significance of other life forms in order to sustain a rich life in a rich world: 
As long as we use technical models in biology without being fully aware that by applying these models we just imply that nature performs according to the projected human requirements and guidelines, we are "blind to the significance (bedeutungsblind)" as Jakob von Uexküll expressed it. We are incapable of putting up questions about the origin and legitimacy of our own needs nor are we capable of asking about the origin and legitimacy of the needs of other living beings. We also cannot investigate the ways in which the needs of the different living beings on this planet are dependent on each other. (T. v. Uexküll 1980: 42-43) ${ }^{2}$

Uexküll described the universe as a creation of countless individual life-worlds and thus challenged the idea of one universally valid world. According to him the idea of the universal world was a "metaphysically" constructed worldview (Sloterdijk 2004: 249), which by globally expanding the reality of one life-form is blinding it from acknowledging the significance of the reality of other life-forms. Uexküll emphasised that inter-subjective (inter-species) understanding is a central aim of scientific investigation. His science of life is making us responsible for our decisions to acknowledge or to ignore the worlds of our fellow organism. So Uexküll became influential not only for the development of modern ecology and ethology, but also for the development of post-modern philosophy. It provides for an substantial ethical viewpoint in a globalised world - a viewpoint that transcends our presumptuousness and reminds us, that accepting autonomy and diversity helps creating sustainable interrelations. Jakob von Uexküll Jr. (this volume), Jakob von Uexküll's nephew, who founded the Right Livelihood Award in 1980, is encouraging people, who take this viewpoint and act responsible to it.

\section{References}

Agamben, Giorgio 2004. The Open: Man and Animal. Stanford: Stanford University Press.

Beer, Theodor; Bethe, Albrecht; Uexküll, Jakob von (1899). Vorschläge zu einer objectivierenden Nomenklatur in der Physiologie des Nervensystems. Biologisches Centralblatt 19: 517-521.

Brock, Friedrich 1927. Das Verhalten des Einsiedlerkrebses Pagurus arrosor Herbst während des Aufsuchens, Ablösens und Aufpflanzens einer Seerose

${ }^{2}$ Translated by T. R. 
Sagartia parasitica Gosse. Wilhelm Roux'Archiv für Entwicklungsmechanik 112: 104-242.

Brecher, Gerhard 1932. Die Entstehung und biologische Bedeutung der subjektiven Zeiteinheit, des Moments. Inaug. Diss. Universität Kiel.

Beniuc, M. 1933. Bewegungssehen, Verschmelzung und Moment bei Kampffischen. Zeitschrift für vergleichende Physiologie 19(4): 724-746.

Cassirer Ernst 1944. An Essay on Man: An Introduction to a Philosophy of Human Culture. New Haven: Yale University Press.

Chamberlain, Houston Stewart 1928. Natur und Leben. Edited by Jakob von Uexküll. München: F. Bruckmann A.-G.

Emmeche Claus 2001. Does a robot have an Umwelt? Reflections on the qualitative biosemiotics of Jakob von Uexküll. Semiotica 134(1/4): 653-693.

Figge, Udo L. 2001. Jakob von Uexküll: Merkmale and Wirkmale. Semiotica 134(1/4): 193-200.

Goldschmidt Richard B. 1956. Portraits from Memory: Recollections of a Zoologist. Seattle: University of Washington Press.

Harrington, Anne 1996. Reenchanted Science: Holism in German Culture from Wilhelm II to Hitler. Princeton: Princeton University Press.

Haupt, Walther 1913. Das von Uexküll'sche Erregungsgesetz geprüft am dritten Gelenk der Krebsschere. Zeitschrift für Biologie 60(11/12): 457-480.

Heusden, Barend Van 2001. Jakob von Uexküll and Ernst Cassirer. Semiotica 134(1/4): 275-292.

Holst, Erich von; Mittelstaedt, Horst 1950. Das Reafferenzprinzip. Die Naturwissenschaften 37: 464-476.

Hünemörder, Christian 1979. Jakob von Uexküll (1864-1944) und sein Hamburger Institut für Umweltforschung. In: Scriba, Christoph J. (ed.), Disciplinae novae: Zur Entstehung neuer Denk- und Arbeitsrichtungen in der Naturwissenschaft. Festschrift zum 90. Geburtstag von Hans Schimank (= Veröffentlichung der Joachim Jungius-Gesellschaft der Wissenschaften Hamburg Nr. 36). Göttingen, 105-125.

Kelso, J. A. Scott 1995. Dynamic Patterns: The Self-Organization of Brain and Behavior. Cambridge: MIT Press.

Kühl, Heinrich 1965. Zwei Hamburger Jubiläen: Zum 100jährigen Gründungstag des Hamburger Aquariums im ehemaligen Zoologischen Garten und zum 100jährigen Geburtstag seines letzten Direktors, Professor Dr. Jakob von Uexküll. Abhandlungen und Verhandlungen des Naturwissentschaftlichen Vereins in Hamburg, N.F. 9, [1964]: 4-15.

Kull, Kalevi 1999. Biosemiotics in the twentieth century: a view from biology. Semiotica 127(1/4): 385-414.

- 2001. Jakob von Uexküll: An introduction. Semiotica 134(1/4): 1-59.

Lagerspetz, Kari Y. 2001. Jakob von Uexküll and the origins of cybernetics. Semiotica 134(1/4): 643-651.

Lissmann, Hans W. 1932. Die Umwelt des Kampffisches [Betta spledens] Regan. Zeitschrift für vergleichende Physiologie 18(1): 65-111.

- 1951. Continous electric signals from the tail of a fish, Gymnarchus niloticus. Nature 167: 201-202. 
Lorenz, Konrad 1935. Der Kumpan in der Umwelt des Vogels. Journal für Ornithologie 83: 137-213, 289-413.

Meyer, Adolf 1934. Ideen und Ideale der biologischen Erkenntnis. Leipzig: Barth.

Mislin, Hans 1978. Jakob von Uexküll (1864-1944), Pionier des verhaltensphysiologischen Experiments. In: Stamm, R. A.; Zeier, H. (eds.), Die Psychologie des 20. Jahrhunderts, Bd. 6. Zürich: Kindler.

Nerlich, Brigitte (1992). Semantic development and semantic change - with special reference to metaphor and metonymy: An overview of theories from 1950 to 1990. http://www.psyc.leeds.ac.uk/research/metaphor/SemDev/ (17.5. 2004).

Rizzolatti, Giacomo; Fadiga, Luciano; Fogassi, Leonardo; Gallese, Vittorio 1997. The space around us. Science 277: 190-191.

Roepstorff, Andreas 2001. Brains in scanners: An Umwelt of cognitive neuroscience. Semiotica 134(1/4): 747-765.

Rosenblatt, Frank 1958. The perceptron: A probabilistic model for information storage and organization in brain. Psychological Review 65: 386 - 408.

Rosenblueth, Arturo; Wiener, Norbert; Bigelow, Julian 1943. Behavior, purpose, and teleology. Philosophy of Science 10: 18-24.

Rowland, William J. 1999. Studying visual cues in fish behavior: a review of ethological techniques. Environmental Biology of Fishes 56: 285-305.

Sarris, Emanuel 1931. Sind wir berechtigt vom Wortverständnis des Hundes zu sprechen. Zeitschrift für angewandte Psychologie 62: 1-139.

Schmidt, Jutta 1975. Jakob von Uexküll und Houston Stewart Chamberlain: Ein Briefwechsel in Auszügen. Medizinhistorisches Journal 10: 121-129.

- 1980. Die Umweltlehre Jakob von Uexkülls in ihrer Bedeutung für die Entwicklung der vergleichenden Verhaltensforschung. Diss. Marburg.

Schult, Joachim (ed.) 2004. Biosemiotik - paktische Anwendungen und Konsequenzen für die Einzelwissenschaften. (Studien zur Theorie der Biologie 6.) Berlin: VWB.

- 1979. The Sign and Its Masters. Austin: University of Texas Press.

- 2001. Biosemiotics: Its roots, proliferation, and prospects. Semiotica 134(1/4): $61-78$.

Sloterdijk, Peter 2004. Sphären III, Schäume. Frankfurt a.M.: Suhrkamp.

Stjernfelt, Frederik 2001. A natural symphony? To what extent is Uexküll's Bedeutungslehre actual for the semiotics of our time? Semiotica 134(1/4): 79102

Sucker, Ulrich 2002. Das Kaiser Wilhelm Institut für Biologie, Seine Gründungsgeschichte, seine problemgeschichtlichen und wissenschaftstheoretischen Voraussetzungen. Stuttgart: Steiner.

Sutrop, Urmas 2001. Umwelt - word and concept: Two hundred years of semantic change Semiotica 134(1/4): 447-462.

Tinbergen, Nicolaas 1942. An objectivistic study of the innate behaviour of animals. Bibliotheca biotheoretica 1: 39-98.

Uexküll, Gudrun von 1964. Jakob von Uexküll - seine Welt und seine Umwelt. Hamburg: Christian Wegner Verlag. 
Uexküll, Jakob von 1904a. Studien über den Tonus II. Die Bewegungen der Schlangensterne. Zeitschrift für Biologie 46: 1-37.

- 1904b. Die ersten Ursachen des Rhythmus in der Tierreihe. Ergebnisse der Physiologie 3(2. Abt.): 1-11.

- 1905a. Leitfaden in das Studium der experimentellen Biologie der Wassertiere. Wiesbaden: J.F.Bergmann.

- 1905b. Studien über den Tonus III: Die Blutegel. Zeitschrift für Biologie 46: 372-402.

- 1909. Umwelt und Innenwelt der Tiere. Berlin: J. Springer.

- 1917. Darwin und die englische Moral. Deutsche Rundschau 173: 215-242.

- 1920a. Theoretische Biologie. Berlin: Gbr. Paetel.

- 1920b. Staatsbiologie (Anatomie-Physiologie-Pathologie des Staates). Berlin: Verlag von Gebrüder Paetel. (Sonderheft der "Deutschen Rundschau", hrg. Rudolf Pechel).

- 1921. Umwelt und Innenwelt der Tiere. 2. verm. u. verb. Aufl. Berlin: J. Springer.

- 1928. Theoretische Biologie. 2. gänzl. neu bearb. Aufl. Berlin: J. Springer.

- 1933 Staatsbiologie. Anatomie-Physiologie-Pathologie des Staates. $2^{\text {nd }}$ ed. Hamburg: Hanseatische Verlagsanstalt.

- 1946. Der unsterbliche Geist in der Natur: Gespräche. 4.-8. Tsd. Hamburg: Christian Wegner Verlag.

- 1947. Der Sinn des Lebens. Gedanken über die Aufgaben der Biologie. (Mitgeteilt in einer Interpretation der zu Bonn 1824 gehaltenen Vorlesung des Johannes Müller mit einem Ausblick von Thure von Uexküll.) Godesberg: Verlag Helmut Küpper.

- 1949. Nie geschaute Welten. 9.-13. Aufl. Berlin: Suhrkamp.

- 1950. Das allmächtige Leben. Hamburg: Christian Wegner Verlag.

- 2001. Letter to Heinrich Junker. Semiotica 134(1/4): 445-446.

Uexküll, Jakob von; Brock, Friedrich 1927. Atlas zur Bestimmung der Orte in den Sehräumen der Tiere. Zeitschrift für vergleichende Physiologie 5: 167-178.

Uexküll, J. von; Kriszat, Georg 1934 [1956; 1970]. Streifzüge durch die Umwelten von Tieren und Menschen: Ein Bilderbuch unsichtbarer Welten. (Sammlung: Verständliche Wissenschaft, Bd. 21.) Berlin: J. Springer. [Since 1956 published together with the work Bedeutungslehre.] Hamburg: Rowohlt.

Uexküll, J. von; Uexküll, Thure von 1944. Die ewige Frage: Biologische Variationen über einen platonischen Dialog. Hamburg: Marion von Schröder Verlag.

Uexküll Thure von, 1979. Die Zeichenlehre Jakob von Uexküll's. Zeitschrift für Semiotik 1: 37-47.

- (ed.) 1980. Jakob von Uexküll. Kompositionslehre der Natur: Biologie als undogmatische Naturwissenschaft. Ausgewählte Schriften. Herausgegeben und eingeleitet von Thure von Uexküll. Frankfurt am Main: Verlag Ullstein $\mathrm{GmbH}$.

- 1981/1987 Die Zeichenlehre Jakob von Uexküll's. In: Krampen, Martin; Oehler, Klaus; Posner, Roland; Sebeok, Thomas A.; Uexküll, Thure von (eds.), Die Welt als Zeichen: Klassiker der modernen Semiotik. Berlin: 
Severin und Siedler, 233-279. Engl.: The sign theory of Jakob von Uexküll. In: Krampen, Oehler, Posner, Sebeok; Uexküll (eds.), Classics of Semiotics. New York: Plenum Press, 147-179.

Werner, Heinz 1926/1933. Einführung in die Entwicklungspsychologie. Leipzig: Barth.

Wiener, Norbert 1948/61. Cybernetics or Control and Communication in the Animal and in the Machine. Cambridge: MIT Press.

Wieser, Wolfgang 1959. Organismen, Strukturen, Maschinen: Zu einer Lehre vom

Organismus. Frankfurt: Fischer.

\section{Якоб фон Юкскюлл и его институт в Гамбурге: история и значение}

Цель статьи - показать, какие исторические процессы привели к признанию работ Якоба фон Юкскюлла, и подчеркнуть важность гамбургского периода Юкскюлла. Краткий биографический обзор позволяет выявить роль его предшественников, исторического претекста и контекста. Научный обзор описывает результаты исследований Юкскюлла и идеи, которые оказались важными в развитии биологии и когнитивных наук. В статье также опровергается высказываемый иногда тезис, будто идеи Юкскюлла были чисто теоретического или философского характера. Утверждается, что главной целью его работ было сохранение эмпирического метода в биологии и снабжение биологии прочным эпистемологическим основанием. В статье предлагаются некоторые примеры использовании продуктивного сближения истории и теории в исследованиях Юкскюлла, проведенных им в стенах института в Гамбурге (Institut für Umweltforschung).

\section{Jakob von Uexküll ja ta instituut Hamburgis: Ajalugu ja tähtsus}

Artikli eesmärgiks on pakkuda sissevaadet arenguisse, mis aitasid kaasa Jakob von Uexkülli tööde esiletõusule, ning rõhutada Uexkülli tegevuse tähtsust Hamburgis. Lühike biograafiline ülevaade toob esile ajaloolise eelloo ja konteksti osa. Teaduslik ülevaade kirjeldab Uexkülli uurimistulemusi ja ideid, mis osutusid oluliseks bioloogia ja kognitiivteaduste arengus. Lisaks püüab artikkel ümber lükata vahel esitatud arvamust, nagu oleks Uexkülli ideed olnud puhtalt teoreetilise või filosoofilise 
iseloomuga. Kinnitatakse, et tema tööde keskseks eesmärgiks oli empiirilise meetodi säilitamine bioloogias ning bioloogiale kindla epistemoloogilise aluse andmine. Artikkel pakub mõningaid näiteid ajaloo ja teooria lähenemisest teineteisele ning selle tulemuslikust kasutusest Uexkülli uurimistöödes, mis tehti Institut für Umweltforschung ’is Hamburgis. 